\title{
Analisis kualitas makanan terhadap kepuasan wisatawan di harris restaurant pada hotel harris raya kuta
}

\author{
Yorlanita Agustina Sojo ${ }^{1)}$, Ni Made Ariani ${ }^{2)}$ I Nyoman Tri Sutaguna ${ }^{3)}$ \\ ${ }^{1}$ Program Studi Diploma IV Pariwisata, Fakultas Pariwisata, Universitas Udayana \\ Jln. Dr. Goris No. 7 Denpasar \\ Email: 1anisojo03@gmail.com
}

\begin{abstract}
Abstrak
Penelitian ini dilatarbelakangi oleh adanya komplain yang disa mpaikan oleh wisatawan terkait kualitas makanan di Harris Restaurant pada Hotel Harris Raya Kuta. Tujuan dilakukan penelitian ini adalah untuk mengetahui kualitas makanan terhadap kepuasan wisatawan di Harris Restaurant pada Hotel Harris Raya Kuta. Variabel yang digunakan dalam penelitia n ini a dalah kualitas makanan dan kepuasan wisatawan. Jenis data yang digunakan dalam penelitian ini adalalah data kualitatif dan data kuantitatif, sedangkan sumber data yang digunakan adalah data primer dan data sekunder. Teknik pengumpulan data menggunakan teknik observasi, wa wa ncara, kuisioner, dokumentasi, da n studi pustaka. Teknik penentuan sa mpel menggunakan teknik kuota sampling, dengan penentuan jumlah sampel menggunakan Rumus Slovin dan diperoleh sebanyak 100 sampel. Teknik analisis data yang digunakan yaitu a nalisis deskriptif dan a nalisis kuantitatif yang terdiri dari analisis statistik deksriptif dengan

menggunakan Skala Likert, statistik infrensial yang terdiri dari uji validitas, uji reliabilitas, dan Important Performance Analysis. Hasil penelitian ini menunjukan bahwa indikator-indikator yang telah memberikan kepuasan kepada wisa tawan a dalah indikator tingkat kematangan, kesegaran untuk dijadikan makanan, porsi, dan tekstur. Kemudian penila ian wisatawan terhadap kualitas makanan di Harris Restaurant pada HotelHarris Raya Kuta diperoleh skor sebesar 89,92\% atau wisa tawan merasa puas terhadap kualitas makanan di Harris Restaurant pada Hotel Harris Raya Kuta.
\end{abstract}

Kata Kunci: Kualitas Makanan, Kepuasan Wisatawan, dan Restoran.

\begin{abstract}
This Research was motivated by the compla ins submitted by touristsregarding the quality of food in Haris Resta urant at Harris Raya Kuta Hotel. The purpose of this research was findout food quality towards tourists satisfaction in Ha rris Restaurant at Harris Raya Kuta Hotel. The variable used in this resea rch is quality of food and tourists satisfaction. The type of data in this research are qualitative and quantitative data, while the data sources used are primary data and secondary data. Method of collecting data are observation, interview, quitionare, documentation, and literature riview. Sa mpling technique uses quota sa mpling technique by determining the number of samples using the Slovin's Formula and obtained as many as 100 samples. Technique of analyzing data used in this research are descriptive analysis and quantitative analysis consisting of descriptive statistical analysis by using a Likert Scale, inferensial statistical consisting of validity test, reliability test and important Performance Analy sis.The result indicates that indicators that have given satisfaction to tourists are indicators of maturity level indicator, freshness to make food, portion, and tex ture. Then the rating of tourists on the quality of food in Harris Restaurant at Harris Ra ya Kuta Hotel obtained a score of 89,92\% or tourists were satisfied with the qua lity of food in Harris Restaurant at Harris Raya Kuta Hotel.
\end{abstract}

Key Word: Food Quality, Tourist Satisfaction, and restaurant.

\section{PENDAHULUAN}

Indonesia merupakan salah satu negara kepulauan. Berdasarkan data dari Direktoral Jenderal Pemerintahan Umum, Kementrian Dalam Negeri, jumlah pulau di Indonesia hingga tahun 2018 mencapai 17.504 pulau. Selain iut, letak geografis negara Indonesia sebagai negara tropis, mampu menghasilkan keindahan alam dan satwa. Hal ini tentunya memberikan dampak positif terhadap pariwisata Indonesia, karena dari sinilah muncul berbagai macam potensi wisata, baik wisata alam, wisata budaya, maupun wisata buatan. 
Industri pariwisata adalah salah satu industri yang memberikan kontribusi yang besar bagi perekonomian negara Indonesia. Perkembangan industri pariwisata di Indonesia yang semakin pesat, tentunya mampu memberikan dorongan bagi setiap daerah di Indonesia untuk dapat memanfaatkan kekayaan alam maupun kekayaan budayanya untuk dikembangkan menjadi sebuah daya tarik wisata, yang tentunya dapat memberikan dampak bagi pertumbuhan ekonomi apabila dapat dikelola dengan baik.

Bali sebagai salah satu Provinsi di Indonesia. Bali sudah dikenal dunia terutama karena keunggulan di sektor pariwisata. Pariwisata sebagai industri unggulan di Pulau Bali. Keunikan budaya yang dimiliki oleh masyarakat Bali menjadi salah satu daya tarik utama bagi wisatawan domestic maupun wisatawan mancanegara untuk berkunjung ke Bali. Namun disamping itu, tak kalah menarik juga daya tarik wisata alam dan daya Tarik wisata buatan yang ada di Bali. Hal ini tentunya memberikan dampak secara langsung terhadap jumlah kunjungan wisatawan ke Pulau Bali tiap setiap tahunnya. Hampir setiap tahun, jumlah kunjungan wisatawan, baik wisatawan domestik maupun wisatawan mancanegara yang berkunjung ke Bali terus mengalami peningkatan yang cukup signifikan.

Kenaikan jumlah wisatawan ke Bali hampir setiap tahunnya tentu saja membutuhkan fasilitas dan akomodasi sebagai penunjang dan pendukung kelancaran kegiatan pariwisata tersebut. Ketersediaan fasilitas dan akomodasi yang memadai mampu memberikan kemudahan bagi wisatawan untuk memenuhi kebutuhan mereka selama melakukan kegiatan wisata. Hotel sebagai salah satu elemen penting dalam dunia pariwisata. Hotel sebagai salah satu faktor pendukung kegiatan pariwisata yang mempunyai peranan penting dalam penyediaan jasa penginapan, makan dan minum, serta fasilitas lainnya, yang diharapkan dapat memberikan kepuasan bagi setiap wisatawanHotel adalah salah satu jenis akomodasi yang mempergunakan sebagian atau keseluruhan bagian untuk jasa pelayanan penginapan, penyedia makanan dan minuman serta jasa lainnya bagi masyarakat umum yang dikelola secara komersil (Keputusan Menteri Parpostel no Km 94/HK103/MPPT 1987).

Hotel Harris Raya Kuta sebagai salah satu hotel yang menyediakan jasa menginap, pelayanan makan dan minum serta fasilitas lainnya yang diperlukan oleh wisatawan adalah Hotel Harris Raya Kuta. Hotel Harris Raya Kuta adalah Hotel bintang empat yang berlokasi di Jalan Raya Kuta nomor 83 E, Kuta, Badung. Hotel Harris Raya Kuta letaknya cukup strategis yaitu berada di area perbelanjaan \& kuliner Jalan Raya Kuta di Bali. Berjarak hanya 5 menit dari Jogger, 10 menit dari Pantai Kuta, 12 menit dari Bandara Internasional Ngurah Rai, 8 menit dari Krisna Tuban, dan sebagainya.. Adapun data jumlah kunjungan wisatawan yang menginap di Hotel Harris Raya Kuta dari tahun 2014 sampai dengan tahun 2018 dapat dilihat pada Tabel 1.1 berikut:

Tabel 1.1 Jumlah kunjungan wisatawan yang menginap di Hotel Harris Raya Kuta dari tahun 2014 sampai dengan tahun 2018

\begin{tabular}{c|c|c}
\hline Tahun & Tingkat Hunian Kamar & Persentase Pertumbuhan (\%) \\
\hline 2014 & 16.135 & - \\
\hline 2015 & 18.878 & 17,00 \\
\hline 2016 & 19.289 & 5,88 \\
\hline 2017 & 18.370 & $-4,76$ \\
\hline 2018 & 21.185 & 15,32 \\
\hline \multicolumn{2}{|c|}{ Rata-Rata } & $\mathbf{8 , 3 6}$ \\
\hline
\end{tabular}

Sumber: Human Resources Departement, 2019.

Berdasarkan data pada Tabel 1.1 di atas dapat diketahui tingkat hunian kamar di Hotel Harris Raya Kuta menunjukan kondisi yang tidak tetap atau berubah-ubah. Tingkat hunian pada tahun 2014 sebesar 16.135 hunian, selanjutnya di tahun 2015 tingkat hunian naik menjadi 18.878 hunian, kemudian di tahun 
2016 masih mengalami peningkatan yaitu sebesar 19.289 hunian, namun pada tahun 2017 tingkat hunian mengalami penurunan yang cukup signifikan yaitu sebesar 18.370 hunian. Berdasarkan hasil wawancara dengan Pak Adi Adnyana selaku Front Office Manager Hotel Harris Raya Kuta (5 April 2019):

"Penurunan yang terjadi di tahun 2017 disebabkan oleh terjadi erupsi Gunung Agung, sehingga banyak tamu yang membatalkan perjalanan mereka dan berdampak pada tingkat hunian kamar. Hotel biasanya akan mengembalikan sepenuhnya uang tamu apabila terjadi bencana alam, sakit, dan ketinggalan pesawat".

Penurunan jumlah kunjungan wisatawan di tahun sebelumnya berbeda dengan di tahun 2018 yang mengalamai kenaikan yang cukup signifikan yaitu sebesar 21.185 hunian. Berdasarkan hasil wawancara dengan Pak Adi Adnyana selaku Front Office Manager Hotel Harris Raya Kuta (5 April 2019):

"Kenaikan yang terjadi di tahun 2018 dikarenakan Hotel Harris Raya Kuta sebagai salah satu hotel dengan letak yang cukup strategis yakni berada dekat dengan beberapa daya tarik wisata dan pusat perbelanjaan yang mudah dijangkau oleh tamu, disamping itu juga peranan dari Sales \&Marketing Departement dalam melakukan promosi sehingga mampu menarik minat tamu untuk menggunakan fasilitas yang ditawarkan oleh Hotel Harris Raya Kuta. Selain itu manajemen Hotel juga terus melakukan pembenahan dan peningkatan sehingga kedepannya lebih baik dari tahun-tahun sebelumnya, sehingga tingkat hunian lebih meningkat lagi”".

Keberadaan sebuah hotel tentunya didukung dengan adanya berbagai departemen, sehingga kegiatan hotel dapat berjalan dengan lancar dan mencapai target sesuai dengan yang telah direncanakan. Menurut Sulastiyono (2011: 63-186), secara umum ada delapan departemen utama yang dimiliki oleh sebuah hotel seperti Front Office Departement, Housekeeping Departement, Food and Beverage Departement, Marketing and Sales Departement, Accounting Departement, Human Resource Departement, Engineering Departement, dan Security Departement. Setiap departemen telah memiliki tugas dan tanggung jawabnya masing-masing.

Food and Beverage Departement adalah salah satu departemen utama yang ada di Hotel Harris Raya Kuta. Food and Beverage Departement yaitu bagian yang bertugas mengolah, memproduksi, dan menyajikan makanan dan minuman untuk keperluan tamu hotel, baik dalam kamar, restaurant, coffe shop, banquet, makanan karyawan, dan sebagainya (Rachman Arief, 2015:113). Soekasno dan Pendit dalam Putra (2018:6), Food and Beverage Departement bertanggung jawab untuk memberikan kepuasan kepada tamu melalui penyajian makanan yang berkualitas sehingga memberikan kepuasan kepada tamu, karena keberahasilan sebuah hotel tidak hanya dipengaruhi oleh tingkat hunian kamar atau kegiatan lainnya, akan tetapi salah satu hal yang paling penting adalah kualitas makanan yang sesuai dengan harapan tamu.

Pada penelitian ini, Human Resources Department Hotel Harris Raya Kuta memberikan izin kepada peneliti untuk pengambilan data jumlah wisatawan yang melakukan breakfast, lunch, dan dinner hanya dalam kurun waktu 6 bulan saja, yaitu dari bulan Juli- Desember 2018. Berikut disajikan data wisatawan yang melakukan breakfast,lunch, dan dinner di Harris Restaurant Hotel Harris Raya Kuta dari bulan Juli - Desember 2018 dapat dilihat pada Tabel 1.2 berikut:

Tabel 1.2 Jumlah Wisatawan yang Melakukan Breakfast, Lunch, dan Dinner di Harris Restaurant Hotel Harris Raya Kuta Pada Bulan Juli-Desember 2018

\begin{tabular}{l|l|l}
\hline \multirow{2}{*}{ Bulan } & \multicolumn{2}{|c}{ Jumlah Orang/Pax } \\
\cline { 2 - 3 } & Breakfast & Lunchdan Dinner \\
\hline
\end{tabular}




\begin{tabular}{c|c|c}
\hline & & 1.447 \\
\hline Juli & 1.207 & 989 \\
\hline Agustus & 1.599 & 1.007 \\
\hline September & 1.042 & 777 \\
\hline Oktober & 1.044 & 765 \\
\hline November & 397 & 1.143 \\
\hline Desember & 1.569 & $\mathbf{6 . 1 2 8}$ \\
\hline Total & $\mathbf{6 . 8 5 8}$ & \\
\hline
\end{tabular}

Sumber : Human Resources Department,2019.

Food \& Beverage Departement Hotel Harris Raya Kuta belum sepenuhnya mampu memberikan kepuasan kepada wisatawan melalui makanan yang disajikan. Masih terdapat banyak komplain yang disampaikan oleh wisatawan. Berikut pada Tabel 1.3 dan Tabel 1.4 disajikan data komplain yang disampaikan oleh wisatawan baik yang secara langsung ke hotel maupun melalui online booking (Trip Advisior dan Booking.Com.).

Tabel 1.3 Jenis dan Jumlah Wisatawan Komplain di Hotel Harris Raya Kuta Pada Bulan JanuariDesember 2018

\begin{tabular}{c|l|l|l|l|l|l|l|l|l|l|l|l|l|l}
\hline No & \multirow{2}{*}{$\begin{array}{l}\text { Jenis } \\
\text { Komplain }\end{array}$} & \multicolumn{10}{|c}{ Bulan } \\
\cline { 3 - 9 } & & $\mathbf{1}$ & $\mathbf{2}$ & $\mathbf{3}$ & $\mathbf{4}$ & $\mathbf{5}$ & $\mathbf{6}$ & $\mathbf{7}$ & $\mathbf{8}$ & $\mathbf{9}$ & $\mathbf{1 0}$ & $\mathbf{1 1}$ & $\mathbf{1 2}$ & Jumlah (0rang) \\
\hline 1 & $\begin{array}{l}\text { Makanan } \\
\text { kurang } \\
\text { bervariasi }\end{array}$ & 5 & 3 & 5 & 3 & 4 & 8 & 5 & 4 & 4 & 3 & 4 & 5 & 53 \\
\hline 2 & $\begin{array}{l}\text { Rasa } \\
\text { makanan }\end{array}$ & 1 & 1 & 0 & 1 & 1 & 2 & 3 & 3 & 3 & 2 & 3 & 4 & 24 \\
\hline 3 & $\begin{array}{l}\text { Presentasi } \\
\text { makanan } \\
\text { kurang } \\
\text { menarik }\end{array}$ & 2 & 5 & 2 & 3 & 3 & 2 & 3 & 0 & 2 & 0 & 2 & 4 & 28 \\
\hline
\end{tabular}

Sumber: Hasil Olah Data,2019.

Berdasarkan Tabel 1.3 di atas, dapat dilihat bahwa total komplain mencapai 105 komplain. Menurut Edwin Pradana selaku FB Supervisior Hotel Harris Raya Kuta (29 Maret 2019):

"apabila total komplain mencapai 100 komplain artinya masuk dalam kategori banyak, sedangkan jika total komplain dibawah 100 artinya bahwa total komplain masuk dalam kategori sedikit”.

Jenis komplain tertinggi yaitu makanan kurang bervariasi dengan total komplain sebesar 53 komplain, berikutnya adalah presentasi makanan kurang menarik dengan total komplain sebesar 28 komplain, dan selanjutnya rasa makanan dengan total komplain sebesar 24 komplain. Adapun penyebab sering terjadinya komplain karena keterbatasan karyawan yang dimiliki, sehingga pada saat situasi crowded menyulitkan karyawan untuk dapat menyajikan makanan sesuai dengan keinginan dari wisatawan, dan juga sulit untuk mengontrol dan mengecek kembali makanan sebelum disajikan ke wisatawan.

Berikut komplain yang disampaikan oleh wisatawan melalui online booking (Trip Advisior dan Booking.Com.) dapat dilihat pada Tabel 1.4 berikut: 
Tabel 1.4 Data ulasan dari Trip Advisior dan Booking.Com Tahun 2018

\begin{tabular}{|c|c|}
\hline Trip Advisior & Booking.Com \\
\hline $\begin{array}{l}\text { 1) Hesky Rorie: } \\
\text { Nilai makanannya kurang,terakhir makan } \\
\text { disana, semua makanannya keasinan } \\
\text { 2) Hendrik Suyono: } \\
\text { Rasa makanan biasa saja dan variasi yang tidak } \\
\text { banyak } \\
\text { 3) Irnas Pratama: } \\
\text { Sa rapan tidak enak, jauh dari ekspetasi standar } \\
\text { HotelHarris lain. } \\
\text { 4) Da vid: } \\
\text { I hope Harris improve its breakfast food. I will } \\
\text { be appreciate more variety dishes and } \\
\text { availability especially for egg station. }\end{array}$ & $\begin{array}{l}\text { 1) Ellena: } \\
\text { Should improve on food, it's to minim variety } \\
\text { 2) Shankar: } \\
\text { The food should have more details with respect } \\
\text { to ingredients like Vegan, vegetarian, Animal } \\
\text { meat, etc } \\
\text { 3) Selena } \\
\text { Makananya tidak enak, kurang bervariasi, tidak } \\
\text { sepertiHaris-Haris lain. }\end{array}$ \\
\hline
\end{tabular}

Sumber: Hasil Olah Data, 2019.

Berdasarkan pada Tabel 1.4 di atas, dapat dilihat bahwa ada 5 tamu yang memberikan ulasan di Trip Advisior dan Booking.Com mengenai makanan yang disajikan oleh Hotel Harris Raya Kuta seperti nilai makananya kurang, rasa makanan kurang enak, sedikit variasi, dan makanannya harus ditingkatkan lagi.

Banyaknya komplain yang disampaikan oleh tamu mengenai kualitas makanan yang disajikan oleh Hotel Harris Raya Kuta baik secara langsung maupun melalui Trip Advisior dan Booking.Com, membuat penulis tertarik untuk melakukan penelitian dengan judul "Analisis Kualitas Makanan Terhadap Kepuasan Wisatawan di Harris Restaurant pada Hotel Harris Raya Kuta”.

\section{METODE PENELITIAN}

Penelitian ini dilakukan di Hotel Harris Raya Kuta, yang terletak di Jalan Raya Kuta, nomor 83 E, Kecamatan Kuta, Kabupaten Badung, Bali. Pemilihan Hotel Harris Raya Kuta sebagai lokasi penelitian dikarenakan adanya komplain yang disampaikan oleh wisatawan baik secara langsung ke Hotel maupun melalui online booking (Trip Advisior dan Booking. Com).

Jenis data yang digunakan dalam penelitian ini adalah data kualitatif dan data kuantitatif. Sumber data yang digunakan dalam penelitian ini adalah data primer dan data sekunder. Teknik pengumupulan data menggunakan teknik observasi terstruktur, kuisioner, wawancara tersturktur, dokumentasi, dan studi pustaka. Teknik penentuan informan menggunakan teknik purposive sampling. Teknik penentuan populasi dan sampel menggunakan kuota sampling dengan perhitungan menggunakan Rumus Slovin dan diperoleh 100 responden, sedangkan pengambilan jumlah sampel menggunakan teknik incidental sampling. Teknik analisis data yang digunakan yaitu analisis deskriptif dan analisis kuantitatif yang terdiri dari analisis statitistik deskriptif dengan menggunakan Skala Likert, statistik inferensial yang terdiri dari uji validitas, uji reliabilitas, dan Important Performance Analysis.

\section{HASIL DAN PEMBAHASAN}

\subsection{Karateristik Wisatawan yang Melakukan Breakfasr,Lunch,dan Dinner di Harris Restaurant pada Hotel Harris Raya Kuta}

Data yang diperoleh pada penelitian dijelaskan secara deskriptif dengan penyajian dalam bentuk yang sederhana. Perhitungan statistik sederhana ini dapat mmapu memberikan gambaran mengenai pendapat wisatawan yang berbentuk angka, selanjutnya di deskripsikan atau dijelaskan sehingga dapat diambil kesimpulan terkait keinginan dan kebutuhan wisatawan. 
Hasil analisis ini dapat menentukan prioritas perbaikan, evaluasi, dan peningkatan oleh manajemen Hotel Harris Raya Kuta. Pada penelitan ini diperoleh sampel wisatawan sebanyak 100 orang. Berikut hasil dari karakteristik wisatawan dapat dilihat pada Diagram Karakteristik Wisatawan yang Melakukan Breakfast, Lunch, dan dinner di Harris Restaurant Pada Hotel Harris Raya Kuta berdasarkan jenis kelamin, pekerjaan, asal, dan usia wisatawan:

\section{1.) Diagram Karakteristik Wisatawan Berdasarkan Jenis Kelamin.}

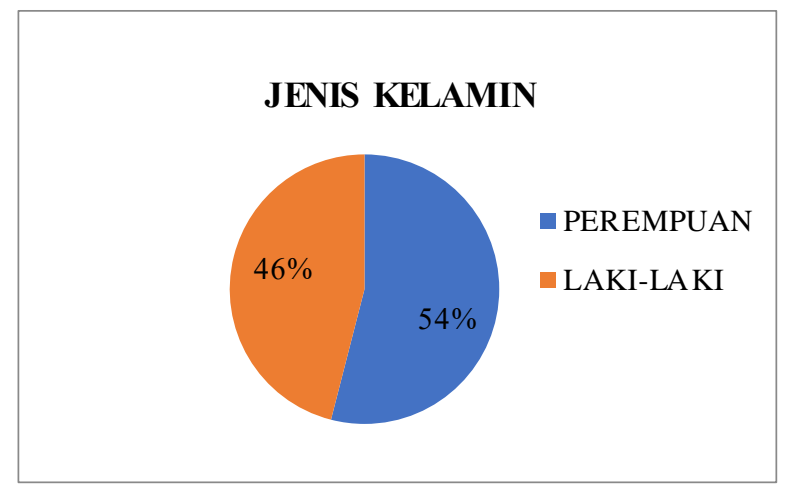

Sumber: Hasil Olah Data, 2019.

Gambar 3.1 Diagram Karakteristik Wisatawan Berdasarkan Jenis Kelamin

Berdasarkan pada Diagram 3.1 di atas, wisatawan yang melakukan breakfast,lunch, dan dinner di Harris Restaurant pada Hotel Harris Raya Kuta berjenis kelamin laki-laki dan perempuan. Wisatawan berjenis kelamin perempuan lebih banyak dengan jumlah total 54 orang atau 54\%, sedangkan wisatawan yang berjenis kelamin laki-laki dengan jumlah total 46 orang atau $46 \%$. Hal ini menunjukan bahwa wisatawan berjenis kelamin perempuan lebih banyak melakukan breakfast, lunch, dan dinner di Harris Restaurant Pada Hotel Harris Raya Kuta.

\section{2.) Diagram Karakteristik Wisatawan Berdasarkan Pekerjaan}

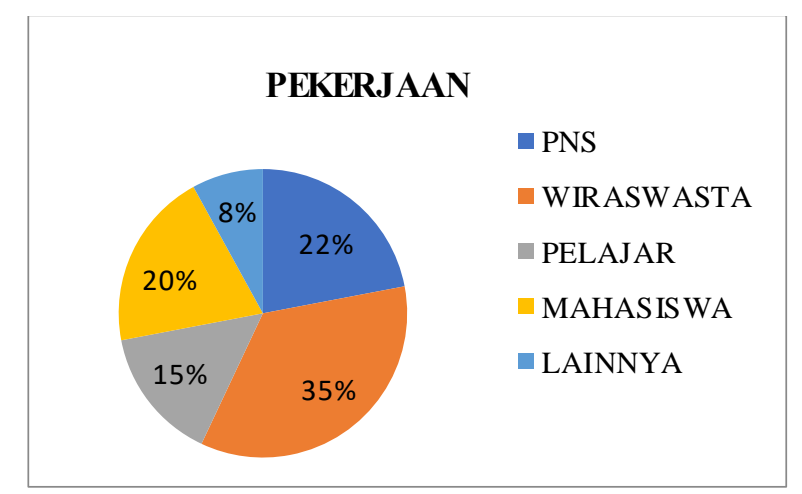

Sumber: Hasil Olah Data, 2019.

Gambar 3.2 Diagram Karakteristik Wisatawan Berdasarkan Pekerjaan

Berdasarkan pada Diagram 3.2 diatas, pekerjaan dari wisatawan yang melakukan breakfast, lunch, dan dinner di Harris Restaurant Pada Hotel Harris Raya Kuta berdasarkan hasil jawaban kuisioner yang terbanyak yaitu wisatawan yang bekerja sebagai wiraswasta, dengan jumlah total 35 orang atau 35\%, selanjutnya PNS sebanyak 22 orang atau 22\%, kemudian mahasiswa sebanyak 20 orang atau 20\%, pelajar sebanyak 15 orang atau $15 \%$, dan lainnya sebanyak 8 orang atau $8 \%$. Wisatawan yang bekerja 
sebagai wiraswasta banyak yang melakukan liburan dengan keluarga ke Bali dan para wisatawan tersebut melakukan breakfast, lunch, dan dinner di Harris Restaurant pada Hotel Harris Raya Kuta.

\section{3.) Diagram Karakteristik Wisatawan Berdasarkan Asal}

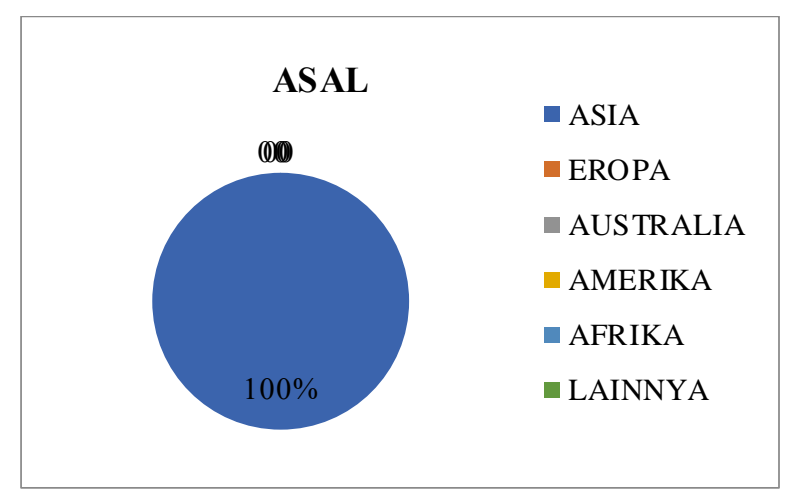

Sumber: Hasil Olah Data, 2019.

Gambar 3.3 Diagram Karakteristik Wisatawan Berdasarkan Asal

Berdasarkan Diagram 3.3 di atas, asal dari wisatawan yang melakukan breakfast, lunch, dan dinner di Harris Restaurant Pada Hotel Harris Raya Kuta berdasarkan hasil jawaban pada kuisioner yaitu secara keseluruhan berasal dari Asia dengan jumlah total 100 orang atau 100\%. Hal ini dipengaruhi oleh segmentasi pasar dari Hotel Harris Raya Kuta adalah wisatawan domestik secara khusus Indonesia.

\section{4.) Diagram Karakteristik Wisatawan Berdasarkan Usia}

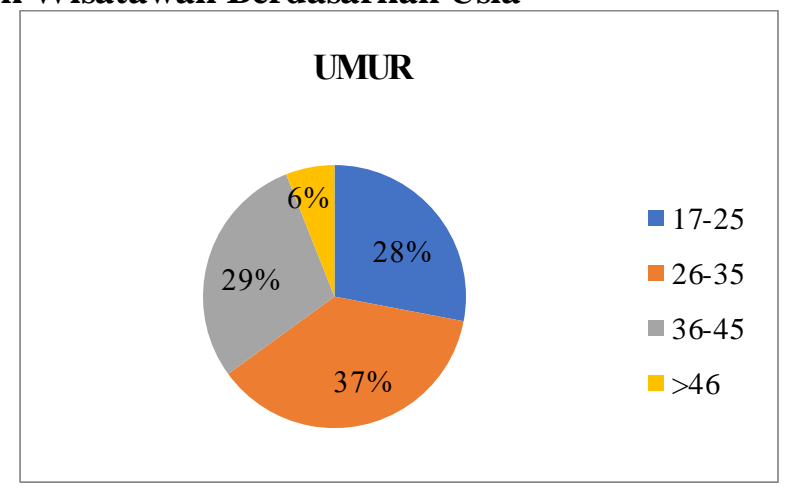

Sumber: Hasil Olah Data, 2019.

Gambar 3.4 Diagram Karakteristik Wisatawan Berdasarkan Umur

Berdasarkan Diagram 3.4 diatas, usia dari wisatawan yang melakukan breakfast, lunch, dan dinner di Harris Restaurant pada Hotel Harris Raya Kuta berdasarkan hasil jawaban pada kuisioner yang terbanyak yaitu wisatawan yang berusia 26 - 35 tahun dengan jumlah total 37 orang atau $37 \%$, selanjutnya usia 36 - 45 tahun dengan jumlah total 29 orang atau $29 \%$, kemudian usia 17 - 25 dengan jumlah total 28 orang atau $28 \%$, dan usia $>46$ dengan jumlah total 6 orang atau $6 \%$.

\subsection{Uji Validitas dan Uji Reliabilitas}

\section{1.) Uji Validitas Indikator Kualitas Makanan}

Uji validitas merupakan esensi dari kebenaran penelitian, yaitu suatu ukuran yang menunjukan tingkat kevalidtan suatu instrumen penelitian. Pengujian validitas tiap butir digunakan analisisi item, 
yaitu mengkorelasikan skor tiap butir dengan skor total yang merupakan jumlah tiap skor butir. Syarat minimum untuk dianggap memenuhi syarat adala jika $r_{k r i t i s}=0,3$. Jadi jika korelasi antara skor butir dengan skor total kurang dari 0,3, maka butir dalam instrumen tersebut dinyatakan tidak valid (Masrun dalam Sugiyono, 2014:133)

Pada Tabel 3.1 berikut disajikan data hasil uji validitas dari seluruh indikator dalam penelitian ini dengan menggunakan program spss versi 25 for windows.

Tabel 3.1 Hasil Uji Validitas Indikator Kualitas Makanan Di Harris Restaurant Pada Hotel Harris Raya Kuta

\begin{tabular}{|c|c|c|c|c|}
\hline No & Indikator & Pernyataan & $\mathbf{r}$-hitung & Keterangan \\
\hline 1.) & Warna & $\begin{array}{l}\text { Kombinasi wa rna makanan yang } \\
\text { disajikan oleh Harris Restaurant } \\
\text { terlihat menarik untuk dimakan }\end{array}$ & 0,755 & Valid \\
\hline 2.) & Penampilan & $\begin{array}{l}\text { Makanan yang disajikan oleh Harris } \\
\text { Restaurant memiliki penampilan yang } \\
\text { menarik untuk dimakan }\end{array}$ & 0,739 & Valid \\
\hline 3.) & Rasa & $\begin{array}{l}\text { Rasa dari makanan yang disajikan oleh } \\
\text { Harris Restaurant memiliki kombinasi } \\
\text { yang tepat sehingga terasa enak saat } \\
\text { dimakan }\end{array}$ & 0,724 & Valid \\
\hline 4.) & Bentuk & $\begin{array}{l}\text { Bentuk makanan yang disajikan oleh } \\
\text { Harris Restaurant terlihat unik } \\
\text { dan memiliki bentuk potongan yang } \\
\text { bervariasi }\end{array}$ & 0,662 & Valid \\
\hline 5.) & Porsi & $\begin{array}{l}\text { Makanan yang disajikan oleh Harris } \\
\text { Restaurant sudah memenuhi sta ndar } \\
\text { porsi sesuai dengan jenis hidangan } \\
\text { yang disajikan }\end{array}$ & 0,499 & Valid \\
\hline 6.) & Tekstur & $\begin{array}{l}\text { Tekstur makanan sudah sesuai dengan } \\
\text { jenis hida ngan yang disajikan oleh } \\
\text { Harris Restaurant }\end{array}$ & 0,573 & Valid \\
\hline 7.) & $\begin{array}{l}\text { Tingkat } \\
\text { Kematangan }\end{array}$ & $\begin{array}{l}\text { Makanan yang disajikan oleh Harris } \\
\text { Restaurant memiliki tingkat } \\
\text { kematangan sesuai dengan jenis } \\
\text { hida ngan yang disajikan, sehingga baik } \\
\text { untuk dimakan }\end{array}$ & 0,672 & Valid \\
\hline 8.) & Temperatur & $\begin{array}{l}\text { Makanan diHarris Restaurant } \\
\text { disajikan dengan suhu yang tepat dan } \\
\text { disesuaikan dengan jenis hidangannya }\end{array}$ & 0,370 & Valid \\
\hline 9.) & $\begin{array}{l}\text { Ketahanan } \\
\text { Makanan }\end{array}$ & $\begin{array}{l}\text { Makanan yang disajikan oleh Harris } \\
\text { Restaurant dapat bertahan dengan baik } \\
\text { wa laupun sudah disajikan dalam } \\
\text { waktu yang cukup lama }\end{array}$ & 0,426 & Valid \\
\hline 10.) & $\begin{array}{l}\text { Kesegaran Untuk } \\
\text { dijadikan Makanan }\end{array}$ & $\begin{array}{l}\text { Makanan yang disajikan oleh Harris } \\
\text { Restaurant dibuat dari bahan-bahan } \\
\text { makanan yang segar, sehingga terasa } \\
\text { enak saat dimakan }\end{array}$ & 0,662 & Valid \\
\hline
\end{tabular}

Sumber: Hasil Olah Data, 2019.

Pada Tabel 3.1 di atas, dapat diketahui hasil uji validitas 10 indikator kualitas makanan yaitu warna, penampilan, rasa, bentuk, porsi, tekstur, tingkat kematangan, temperature, ketahanan makanan, dan kesegaran untuk dijadikan makanan dengan nilai $r_{\text {hitung }}$ lebih besar dari nilai $r_{\text {kritis }} 0,3$, hal ini menunjukan bahwa 10 indikator yang digunakan pada penelitian ini adalah valid.

\section{2.) Uji Reliabilitas Variabel Kualitas Makanan}


Uji Reliabilitas digunakan untuk mengetahui apakah instrumen tersebut dapat di percaya, handal dan akurat. Suatu instrumen dikatakan reliabel dengan tingkat signifikan pada nilai alpha cronbach > 0,6 (Bhuono dalam Putra, 2018:20). Pada Tabel 3.2 berikut disajikan data hasil uji reliabilitas dari seluruh indikator dalam peneliitan ini dengan menggunakan program spss versi 25 for windows:

Tabel 3.2 Hasil Uji Reliabiltas Variabel Kualitas Makanan di Harris Restaurant Pada Hotel Harris Raya Kuta

\begin{tabular}{c|c|c}
\hline Variabel & Cronbach's Alpha & Keterangan \\
\hline Kua litas Makanan & 0,817 & Reliabel \\
\hline
\end{tabular}

Sumber: Hasil Olah Data, 2019.

Beradasarkan Tabel 3.2 dapat diketahui hasil uji reliabiltas variabel kualitas makanan di Harris Restaurant Pada Hotel Harris Raya Kuta memiliki nilai Cronbach's Alpha lebih besar dari 0,6. Sehinga hasil tersebut menunjukan bahwa variabel yang digunakan dalam penelitian ini adalah reliabel.

\subsection{Analisis Indikator-Indikator Kualitas Makanan Terhadap Kepuasan Wisatawan Di Harris Restaurant Pada Hotel Harris Raya Kuta}

1. Penilaian Wisatawan Terhadap Kualitas Makanan Di Harris Restaurant Pada Hotel Harris Raya Kuta

Kuisioner disebar ke 100 wisatawan guna untuk mengetahui penilaian wisatawan terhadap kualitas makanan di Harris Restaurant Pada Hotel Harris Raya Kuta dengan memberikan 10 pernyataan dan 4 kriteria penilaian sebagai berikut:
1) SS
= Sangat Setuju
Nilai 4
2) $S$
$=$ Setuju
Nilai 3
3) TS
$=$ Tidak Setuju
Nilai 2
4) STS
$=$ Sangat Tidak Setuju
Nilai 1

Selanjutnya, hasil olah data kuisioner dari 10 indikator kualitas makanan di Harris Restaurant Pada Hotel Harris Raya Kuta dapat dilihat pada Tabel 3.3 berikut:

Tabel 3.3 Penilaian Wisatawan Terhadap Kualitas Makanan di Harris Restaurant Pada Hotel Harris Raya Kuta

\begin{tabular}{|c|c|c|c|c|c|c|c|}
\hline \multirow[t]{3}{*}{ No } & \multirow[t]{3}{*}{ Indikator } & \multicolumn{4}{|c|}{ Kualitas Makanan } & \multirow{3}{*}{ Rata- } & \multirow[t]{3}{*}{ Kategori } \\
\hline & & STS & TS & $\overline{\mathbf{S}}$ & SS & & \\
\hline & & $\begin{array}{c}\text { Skor } \\
1\end{array}$ & Skor 2 & Skor 3 & Skor 4 & & \\
\hline
\end{tabular}

1. Warna

\begin{tabular}{|c|c|c|c|c|c|c|}
\hline $\begin{array}{l}\text { Kombinasi warna } \\
\text { makanan yang disajikan } \\
\text { oleh Ha rris Restaurant } \\
\text { terlihat menarik untuk } \\
\text { dimakan }\end{array}$ & 0 & 21 & 39 & 40 & 1 & Setuju \\
\hline \multicolumn{7}{|l|}{ 2. Penampilan } \\
\hline $\begin{array}{l}\text { Makanan yang disajikan } \\
\text { oleh Ha rris Restaurant } \\
\text { memiliki penampilan } \\
\text { yang menarik untuk } \\
\text { dimakan }\end{array}$ & 0 & 25 & 36 & 39 & 314 & Setuju \\
\hline \multicolumn{7}{|l|}{ 3. Rasa } \\
\hline $\begin{array}{l}\text { Rasa dari makanan yang } \\
\text { disajikan oleh Harris } \\
\text { Restaurant memiliki } \\
\text { kombinasi yang tepat }\end{array}$ & 0 & 24 & 39 & 37 & 313 & Setuju \\
\hline
\end{tabular}




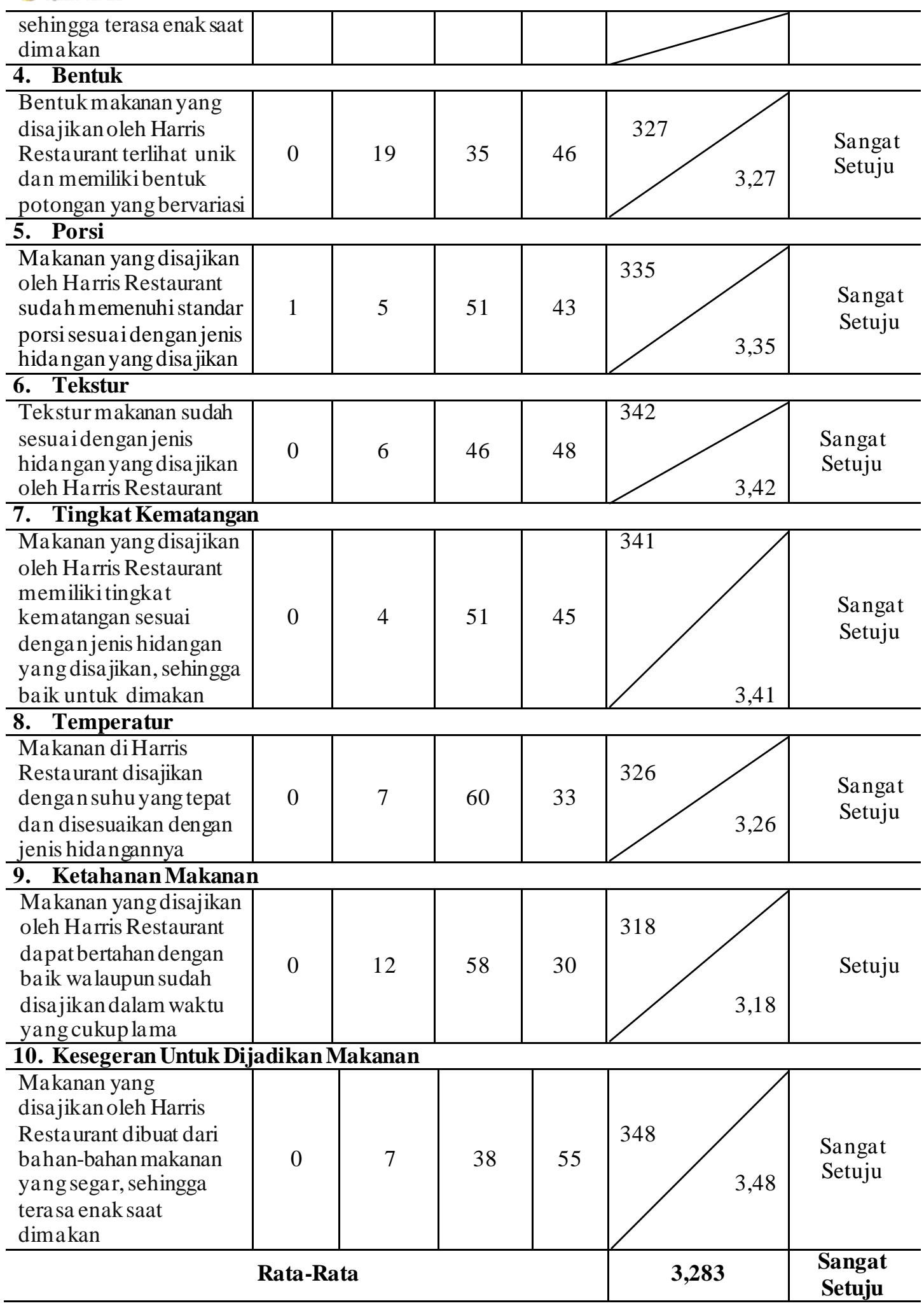

Sumber: Hasil Olah Data, 2019.

Berdasarkan hasil pada Tabel 3.3 diatas, dapat dilihat bahwa hasil penyebaran kuisioner kepada 100 wisatawan yang telah memberikan penilaiannya masing-masing terhadap kualitas makanan di Harris Restaurant Pada Hotel Harris Raya Kuta dengan 10 indikator dapat disimpulkan yaitu untuk indikator warna terdapat 40 wisatawan menyatakan sangat setuju, 39 wisatawan menyatakan setuju, 21 wisatawan menyatakan tidak setuju. Secara keseluruhan penilaian wisatawan untuk indikator warna makanan di Harris Restaurant pada Hotel Harris Raya Kuta adalah 3,19 dengan kategori setuju. 
Indikator penampilan terdapat 39 wisatawan menyatakan sangat setuju, 36 wisatawan menyatakan setuju, 25 wisatawan menyatakan tidak setuju. Secara keseluruhan penilaian wisatawan untuk indikator penampilan makanan di Harris Restaurant pada Hotel Harris Raya Kuta adalah 3,14 dengan kategori setuju. Indikator rasa terdapat 37 wisatawan menyatakan sangat setuju, 39 wisatawan menyatakan setuju, 24 wisatawan menyatakan tidak setuju. Secara keseluruhan penilaian wisatawan untuk indikator rasa makanan di Harris Restaurant pada Hotel Harris Raya Kuta adalah 3,13 dengan kategori setuju. Indikator bentuk terdapat 46 wisatawan menyatakan sangat setuju, 35 wisatawan menyatakan setuju, 19 wisatawan menyatakan tidak setuju. Secara keseluruhan penilaian wisatawan untuk indikator bentuk makanan di Harris Restaurant pada Hotel Harris Raya Kuta adalah 3,27 dengan kategori sangat setuju. Indikator porsi terdapat 43 wisatawan menyatakan sangat setuju, 51 wisatawan menyatakan setuju, 5 wisatawan menyatakan tidak setuju, dan 1 wisatawan menyatakan sangat tidak setuju. Secara keseluruhan penilaian wisatawan untuk indikator porsi makanan di Harris Restaurant pada Hotel Harris Raya Kuta adalah 3,35 dengan kategori sangat setuju. Indikator tekstur, terdapat 48 wisatawan menyatakan sangat setuju, 46 wisatawan menyatakan setuju, 6 wisatawan menyatakan tidak setuju. Secara keseluruhan penilaian wisatawan untuk indikator tekstur makanan di Harris Restaurant pada Hotel Harris Raya Kuta adalah 3,42 dengan kategori sangat setuju. Indikator tingkat kematangan terdapat 45 wisatawan menyatakan sangat setuju, 51 wisatawan menyatakan setuju, 4 wisatawan menyatakan tidak setuju. Secara keseluruhan penilaian wisatawan untuk indikator tingkat kematangan makanan di Harris Restaurant pada Hotel Harris Raya Kuta adalah 3,41 dengan kategori sangat setuju. Indikator temperatur terdapat 33 wisatawan menyatakan sangat setuju, 60 wisatawan menyatakan setuju, 7 wisatawan menyatakan tidak setuju. Secara keseluruhan penilaian wisatawan untuk indikator temperatur makanan di Harris Restaurant pada Hotel Harris Raya Kuta adalah 3,26 dengan kategori sangat setuju. Inidkator ketahanan makanan terdapat 30 wisatawan menyatakan sangat setuju, 58 wisatawan menyatakan setuju, 12 wisatawan menyatakan tidak setuju. Secara keseluruhan penilaian wisatawan untuk indikator ketahanan makanan di Harris Restaurant pada Hotel Harris Raya Kuta adalah 3,18 dengan kategori setuju. Indikator kesegaran untuk dijadikan makanan terdapat 55 wisatawan menyatakan sangat setuju, 38 wisatawan menyatakan setuju, 7 wisatawan menyatakan tidak setuju. Secara keseluruhan penilaian wisatawan untuk indikator kesegaran untuk dijadikan makanan di Harris Restaurant pada Hotel Harris Raya Kuta adalah 3,48 dengan kategori sangat setuju.

Berdasarkan hasil pada Tabel 3.3 total skor rata - rata penilaian wisatawan terhadap kualitas makanan di Harris Restaurant Pada Hotel Harris Raya Kuta adalah sebesar 3,283 atau wisatawan menyatakan sangat setuju terhadap kualitas makanan di Harris Restaurant Pada Hotel Harris Raya Kuta.

2.) Penilaian Tingkat Kepentingan Wisatawan terhadap Kualitas Makanan Di Harris Restaurant Pada Hotel Harris Raya Kuta

Kuisioner disebar ke 100 wisatawan guna untuk mengetahui penilaian tingkat kepentingan wisatawan terhadap kualitas makanan di Harris Restaurant Pada Hotel Harris Raya Kuta dengan memberikan 10 pernyataan dan 4 kriteria penilaian sebagai berikut:

$\begin{array}{lllr}\text { 1) } & \text { SP } & =\text { Sangat Penting } & \text { Nilai } 4 \\ \text { 2) } & \text { P } & =\text { Penting } & \text { Nilai } 3 \\ 3) & \text { TP } & =\text { Tidak Penting } & \text { Nilai } 2 \\ 4) & \text { STP } & =\text { Sangat Tidak Penting Nilai } 1\end{array}$

Selanjutnya, hasil olah data kuisioner dari 10 indikator penilaian tingkat kepentingan wisatawan terhadapa kualitas makanan di Harris Restaurant Pada Hotel Harris Raya Kuta dapat dilihat pada Tabel 3.4 berikut:

Tabel 3.4 Penilaian Tingkat Kepentingan WisatawanTerhadap Kualitas Makanan di Harris Restaurant Pada Hotel Harris Raya Kuta 


\begin{tabular}{|c|c|c|c|c|c|c|c|}
\hline \multirow[t]{3}{*}{ No } & \multirow[t]{3}{*}{ Indikator } & \multicolumn{4}{|c|}{ Kualitas Makanan } & \multirow{3}{*}{ Total Skor } & \multirow[t]{3}{*}{ Kategori } \\
\hline & & STP & $\overline{T P}$ & $\overline{\mathbf{P}}$ & $\mathbf{S P}$ & & \\
\hline & & $\begin{array}{c}\text { Skor } \\
1\end{array}$ & Skor 2 & Skor 3 & Skor 4 & & \\
\hline
\end{tabular}

\section{Warna}

\begin{tabular}{|c|c|c|c|c|c|c|}
\hline $\begin{array}{l}\text { Kombinasi warna } \\
\text { makanan yang disajikan } \\
\text { oleh Ha rris Restaurant } \\
\text { terlihat menarik untuk } \\
\text { dimakan }\end{array}$ & 0 & 0 & 26 & 74 & 1 & $\begin{array}{l}\text { Sangat } \\
\text { Penting }\end{array}$ \\
\hline
\end{tabular}

\section{Penampilan}

\begin{tabular}{l|l|l|l|l|l|l}
\hline $\begin{array}{l}\text { Makanan yang disajikan } \\
\text { oleh Harris Restaurant } \\
\text { memiliki penampilan } \\
\text { yang menarik untuk } \\
\text { dimakan }\end{array}$ & 0 & 2 & 27 & 71 & & \\
\hline
\end{tabular}

\section{Rasa}

\begin{tabular}{|c|c|c|c|c|c|c|}
\hline $\begin{array}{l}\text { Ra sa dari makanan yang } \\
\text { disajikan oleh Harris } \\
\text { Restaurant memiliki } \\
\text { kombinasi yang tepat } \\
\text { sehingga terasa enak saat } \\
\text { dimakan }\end{array}$ & 0 & 1 & 22 & 77 & 376 & $\begin{array}{l}\text { Sangat } \\
\text { Penting }\end{array}$ \\
\hline
\end{tabular}

\section{Bentuk}

\begin{tabular}{l|l|l|l|l|l|l}
\hline $\begin{array}{l}\text { Bentukmakanan yang } \\
\text { disajikan oleh Harris } \\
\begin{array}{l}\text { Restaurant terlihat unik } \\
\text { dan memilikibentuk } \\
\text { potongan yangbervariasi }\end{array}\end{array}$ & 0 & 2 & 35 & 63 & & 361 \\
\hline
\end{tabular}

\section{Porsi}

\begin{tabular}{l|l|l|l|l|l|l}
\hline $\begin{array}{l}\text { Makanan yang disajikan } \\
\text { oleh Harris Restaurant } \\
\text { sudah memenuhi standar } \\
\text { porsi sesuaidenganjenis } \\
\text { hidangan yang disajikan }\end{array}$ & 0 & 0 & 38 & 62 & & 363 \\
\hline
\end{tabular}

\section{Tekstur}

\begin{tabular}{|c|c|c|c|c|c|c|}
\hline $\begin{array}{l}\text { Tekstur makanan sudah } \\
\text { sesuaidenganjenis } \\
\text { hidangan yang disajikan } \\
\text { oleh Ha rris Restaurant }\end{array}$ & 0 & 1 & 33 & 66 & 365 & $\begin{array}{l}\text { Sangat } \\
\text { Penting }\end{array}$ \\
\hline \multicolumn{7}{|l|}{ 7. Tingkat Kematangan } \\
\hline $\begin{array}{l}\text { Makanan yang disajikan } \\
\text { oleh Ha rris Restaurant } \\
\text { memilikitingkat } \\
\text { kematangan sesuai } \\
\text { denganjenis hidangan }\end{array}$ & 0 & 0 & 35 & 65 & 366 & $\begin{array}{l}\text { Sangat } \\
\text { Penting }\end{array}$ \\
\hline
\end{tabular}




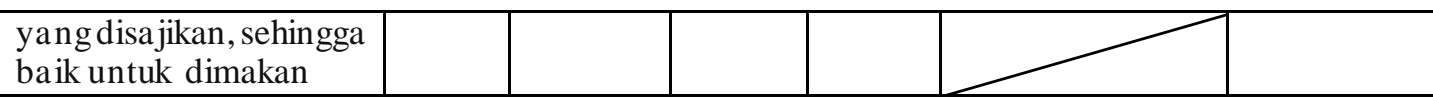

\section{Temperatur}

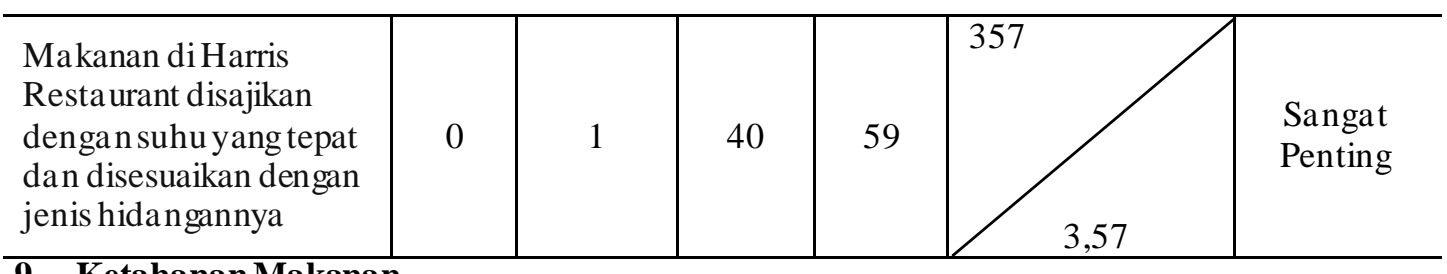

9. Ketahanan Makanan

\begin{tabular}{|c|c|c|c|c|c|c|}
\hline $\begin{array}{l}\text { Makanan yang disajikan } \\
\text { oleh Ha rris Restaurant } \\
\text { da patbertahan dengan } \\
\text { baik wa laupun sudah } \\
\text { disajikan dalam waktu } \\
\text { yang cukup la ma }\end{array}$ & 0 & 2 & 44 & 54 & 352 & $\begin{array}{l}\text { Sangat } \\
\text { Penting }\end{array}$ \\
\hline
\end{tabular}

10. Kesegeran Untuk Dijadikan Makanan

\begin{tabular}{|c|c|c|c|c|c|c|}
\hline $\begin{array}{l}\text { Makanan yang } \\
\text { disajikan oleh Harris } \\
\text { Restaurant dibuat dari } \\
\text { bahan-bahan makanan } \\
\text { yang segar, sehingga } \\
\text { tera sa enak saat } \\
\text { dimakan } \\
\end{array}$ & 0 & 1 & 29 & 70 & 3,69 & $\begin{array}{l}\text { Sangat } \\
\text { Penting }\end{array}$ \\
\hline \multicolumn{5}{|c|}{ Rata-Rata } & 3,283 & $\begin{array}{l}\text { Sangat } \\
\text { Penting }\end{array}$ \\
\hline
\end{tabular}

Sumber: Hasil Olah Data, 2019.

Berdasarkan hasil pada Tabel 3.4 diatas, dapat dilihat bahwa hasil penyebaran kuisioner kepada 100 wisatawan yang telah memberikan penilaian untuk tingkat kepentingan terhadap kualitas makanan di Harris Restaurant Pada Hotel Harris Raya Kuta dengan 10 indikator dapat disimpulkan yaitu indiaktor warna terdapat 74 wisatawan menyatakan sangat penting, 26 wisatawan menyatakan penting. Secara keseluruhan penilaian wisatawan terhadap tingkat kepentingan untuk indikator warna makanan di Harris Restaurant pada Hotel Harris Raya Kuta adalah 3,74 dengan kategori sangat penting. Indikator penampilan terdapat 71 wisatawan menyatakan sangat penting, 27 wisatawan menyatakan penting, 2 wisatawan menyatakan tidak penting. Secara keseluruhan penilaian wisatawan terhadap tingkat kepentingan untuk indikator penampilan makanan di Harris Restaurant pada Hotel Harris Raya Kuta adalah 3,69 dengan kategori sangat penting. Indikator rasa terdapat 77 wisatawan menyatakan sangat penting, 22 wisatawan menyatakan penting, dan 1 wisatawan menyatakan tidak penting. Secara keseluruhan penilaian wisatawan terhadap tingkat kepentingan untuk indikator rasa makanan di Harris Restaurant pada Hotel Harris Raya Kuta adalah 3,76 dengan kategori sangat penting. Indikator bentuk terdapat 63 wisatawan menyatakan sangat penting, 35 wisatawan menyatakan penting, dan 2 wisatawan menyatakan tidak penting. Secara keseluruhan penilaian wisatawan terhadap tingkat kepentingan untuk indikator bentuk makanan di Harris Restaurant pada Hotel Harris Raya Kuta adalah 3,61 dengan kategori sangat penting. Indikator porsi terdapat 62 wisatawan menyatakan sangat penting, 38 wisatawan menyatakan penting. Secara keseluruhan penilaian wisatawan terhadap tingkat kepentingan untuk indikator porsi makanan di Harris Restaurant pada Hotel Harris Raya Kuta adalah 3,63 dengan kategori sangat penting. Indikator tekstur terdapat 66 wisatawan menyatakan sangat penting, 33 wisatawan menyatakan penting, dan 1 wisatawan menyatakan tidak penting. Secara keseluruhan penilaian wisatawan terhadap tingkat kepentingan untuk indikator tekstur makanan di Harris Restaurant pada Hotel Harris Raya Kuta adalah 3,65 dengan kategori sangat penting. Indikator tingkat kematangan 
terdapat 65 wisatawan menyatakan sangat penting, 35 wisatawan menyatakan penting. Secara keseluruhan penilaian wisatawan terhadap tingkat kepentingan untuk indikator tingkat kematangan makanan di Harris Restaurant pada Hotel Harris Raya Kuta adalah 3,66 dengan kategori sangat penting. Indikator temperatur terdapat 59 wisatawan menyatakan sangat penting, 40 wisatawan menyatakan penting, dan 1 wisatawan menyatakan tidak penting. Secara keseluruhan penilaian wisatawan terhadap tingkat kepentingan untuk indikator temperature makanan di Harris Restaurant pada Hotel Harris Raya Kuta adalah 3,57 dengan kategori sangat penting. Indikator porsi terdapat 54 wisatawan menyatakan sangat penting, 44 wisatawan menyatakan penting, dan 2 wisatawan menyatakan tidak penting. Secara keseluruhan penilaian wisatawan terhadap tingkat kepentingan untuk indikator porsi makanan di Harris Restaurant pada Hotel Harris Raya Kuta adalah 3,52 dengan kategori sangat penting. Indikator kesegaran untuk dijadikan makanan terdapat 70 wisatawan menyatakan sangat penting, 29 wisatawan menyatakan penting, dan 1 wisatawan tidak penting. Secara keseluruhan penilaian wisatawan terhadap tingkat kepentingan untuk indikator kesegaran untuk dijadikan makanan di Harris Restaurant pada Hotel Harris Raya Kuta adalah 3,69 dengan kategori sangat penting.

Berdasarkan hasil pada Tabel 3.4 total skor rata - rata penilaian tingkat kepentingan wisatawan terhadap kualitas makanan di Harris Restaurant Pada Hotel Harris Raya Kuta adalah sebesar 3,652 atau wisatawan menyatakan sangat penting kualitas makanan di Harris Restaurant Pada Hotel Harris Raya Kuta.

3.) Tingkat Kesesuaian Kualitas Makanan Terhadap Kepuasan Wisatawan di Harris Restaurant Pada Hotel Harris Raya Kuta

Berdasarkan hasil penilaian tingkat pelaksanaan atau kinerja dan tingkat kepentingan maka dihasilkan suatu perhitungan mengenai tingkat kesesuaian antara tingkat pelaksanaan dan tingkat kepentingan. Menurut Martila dan James dalam Supranto (2011:239), berikut rumus yang digunakan untuk menghitung tingkat kesesuaian:

Rumus: $\quad T k i=\frac{X i}{Y i}$ X 100\%

Dimana: Tki $\quad=$ Tingkat kesesuaian responden

$$
\begin{array}{ll}
\mathrm{Xi} & =\text { Skor penilaian kinerja } \\
\mathrm{Yi} & =\text { Skor penilaian kepentingan pelanggan }
\end{array}
$$

Berikut pada Tabel 3.5 merupakan skor rata-rata dari penilaian kualitas makanan, tingkat kepentingan, dan tingkat kesesuaian kualitas makanan di Harris Restaurant pada Hotel Harris Raya Kuta:

Tabel 3.5 Tabulasi Skor Penilaian Kualitas Makanan, Tingkat Kepentingan, dan Tingkat Kesesuaian Kualitas Makanan terhadap Kepuasan Wisatawan di Harris Restaurant pada Hotel Harris Raya Kuta

\begin{tabular}{l|c|c|c|c|c|c|c}
\hline NO & Indikator & $\begin{array}{c}\text { Skor } \\
\text { Kualitas } \\
\text { Makanan }\end{array}$ & $\begin{array}{c}\text { Skor Tingkat } \\
\text { Kepentingan }\end{array}$ & $\mathbf{X}$ & $\mathbf{Y}$ & $\begin{array}{c}\text { Tingkat } \\
\text { kesesuaian } \\
(\boldsymbol{\%})\end{array}$ & Kategori \\
\hline \multicolumn{1}{|c|}{ 1. Warna } & & & & & \\
\hline $\begin{array}{l}\text { Kombinasi warna } \\
\text { makanan yang disajikan } \\
\text { oleh Ha rris Restaurant } \\
\text { terlihat menarik untuk } \\
\text { dimakan }\end{array}$ & 319 & 374 & 3,19 & 3,74 & 85,29 & Puas \\
\hline $\begin{array}{l}\text { 2. Penampilan } \\
\text { Makanan yang }\end{array}$ & 314 & 369 & 3,14 & 3,69 & 85,09 & Puas \\
\hline
\end{tabular}




\begin{tabular}{|c|c|c|c|c|c|c|}
\hline $\begin{array}{l}\text { Resta urant memiliki } \\
\text { penampilan yang } \\
\text { menarik untuk dimakan }\end{array}$ & & & & & & \\
\hline \multicolumn{7}{|l|}{ 3. Rasa } \\
\hline $\begin{array}{l}\text { Rasa dari makanan } \\
\text { yang disajikan oleh } \\
\text { Harris Restaurant } \\
\text { memiliki kombinasi } \\
\text { yang tepat sehingga } \\
\text { terasa enak saat } \\
\text { dimakan }\end{array}$ & 313 & 376 & 3,13 & 3,76 & 83,24 & Puas \\
\hline \multicolumn{7}{|l|}{ 4. Bentuk } \\
\hline $\begin{array}{l}\text { Bentukmakanan yang } \\
\text { disajikan oleh Harris } \\
\text { Restaurant terlihat unik } \\
\text { dan memilikibentuk } \\
\text { potongan yang } \\
\text { bervariasi }\end{array}$ & 327 & 361 & 3,27 & 3,61 & 90,58 & Puas \\
\hline \multicolumn{7}{|l|}{ 5. Porsi } \\
\hline $\begin{array}{l}\text { Makanan yang } \\
\text { disajikan oleh Harris } \\
\text { Resta urant sudah } \\
\text { memenuhi standar } \\
\text { porsi sesuai dengan } \\
\text { jenis hidangan yang } \\
\text { disajikan }\end{array}$ & 335 & 363 & 3,35 & 3,63 & 92,28 & Puas \\
\hline \multicolumn{7}{|l|}{ 6. Tekstur } \\
\hline $\begin{array}{l}\text { Tekstur makanan sudah } \\
\text { sesuaidenganjenis } \\
\text { hidangan yang } \\
\text { disajikan oleh Harris } \\
\text { Restaurant }\end{array}$ & 342 & 365 & 3,42 & 3,65 & 93,69 & Puas \\
\hline \multicolumn{7}{|l|}{ 7. Tingkat Kematangan } \\
\hline $\begin{array}{l}\text { Makanan yang } \\
\text { disajikan oleh Harris } \\
\text { Restaurant memiliki } \\
\text { tingkat kematangan } \\
\text { sesuaidenganjenis } \\
\text { hidangan yang } \\
\text { disajikan, sehingga baik } \\
\text { untuk dimakan }\end{array}$ & 341 & 366 & 3,41 & 3,66 & 93,16 & Puas \\
\hline \multicolumn{7}{|l|}{ 8. Temperatur } \\
\hline $\begin{array}{l}\text { Makanan di Harris } \\
\text { Resta urant disajikan } \\
\text { dengan suhu yang tepat } \\
\text { dan disesuaikan dengan } \\
\text { jenis hidangannya }\end{array}$ & 326 & 357 & 3,26 & 3,57 & 91,31 & Puas \\
\hline \multicolumn{7}{|l|}{ 9. Ketahanan Makanan } \\
\hline $\begin{array}{l}\text { Makanan yang } \\
\text { disajikan oleh Harris } \\
\text { Resta urant dapat } \\
\text { bertahan dengan baik } \\
\text { walaupun sudah } \\
\text { disajikan dalam waktu } \\
\text { yang cukup lama }\end{array}$ & 318 & 352 & 3,18 & 3,52 & 90,34 & Puas \\
\hline \multicolumn{7}{|c|}{ 10. Kesegaran Untuk Dijadikan Makanan } \\
\hline $\begin{array}{l}\text { Makanan yang } \\
\text { disajikan oleh Harris } \\
\text { Restaurant dibuat dari }\end{array}$ & 348 & 369 & 3,48 & 3,69 & 94,30 & Puas \\
\hline
\end{tabular}




\begin{tabular}{|c|}
\hline $\begin{array}{l}\text { bahan-bahan makanan } \\
\text { yang segar, sehingga } \\
\text { tera sa enak saat } \\
\text { dimakan }\end{array}$ \\
\hline
\end{tabular}

Sumber: Hasil Olah Data, 2019.

Berdasarkan pada Tabel 3.5 di atas dapat dilihat bahwa tabulasi skor penilaian kualitas makanan, tingkat kepentingan, dan tingkat kesesuaian kualitas makanan terhadap kepuasan wisatawan di Harris Restaurant pada Hotel Harris Raya Kuta berdasarkan Important Performance Analyisi (IPA). Dari 10 indikator yang diteliti, 3 indikator memperoleh tingkat kesesuaian dibawah 90\% dengan kategori puas, adapun 3 indikator tersebut yaitu kombinasi warna makanan yang disajikan oleh Harris Restaurant terlihat menarik untuk dimakan, makanan yang disajikan oleh Harris Restaurant memiliki penampilan yang menarik untuk dimakan, dan rasa dari makanan yang disajikan oleh Harris Restaurant memiliki kombinasi yang tepat sehingga terasa enak saat dimakan. Sedangkan 7 indikator lainnya memperoleh tingkat kesesuaian diatas 90\% dengan kategori puas, adapun 7 indikator tersebut yaitu bentuk makanan yang disajikan oleh Harris Restaurant terlihat unik dan memiliki bentuk potongan yang bervariasi, makanan yang disajikan oleh Harris Restaurant sudah memenuhi standar porsi sesuai dengan jenis hidangan yang disajikan, tekstur makanan sudah sesuai dengan jenis hidangan yang disajikan oleh Harris Restaurant, makanan yang disajikan oleh Harris Restaurant memiliki tingkat kematangan sesuai dengan jenis hidangan yang disajikan, sehingga baik untuk dimakan, makanan di Harris Restaurant disajikan dengan suhu yang tepat dan disesuaikan dengan jenis hidangannya, makanan yang disajikan oleh Harris Restaurant dapat bertahan dengan baik walaupun sudah disajikan dalam waktu yang cukup lama, dan makanan yang disajikan oleh Harris Restaurant dibuat dari bahan-bahan makanan yang segar, sehingga terasa enak saat dimakan.

Setelah menghitung tingkat kesesuaian, selanjutnya unur-unsur tersebut dijabarkan dan dibagi menjadi empat bagian kedalam Diagram Kartesius. Diagram Kartesius adalah suatu bangunan yang dibagi atas empat bagian yang dibatasai oleh dua buah garis berpotongan tegak lurus pada titik $\overline{\bar{X}}$ dan $\bar{Y}$, dimana $\bar{X}$ merupakan rata rata dari skor tingkat pelaksanaan dan $\bar{Y}$ adalah rata-rata skor tingkat kepentingan. Adapun rumus untuk menentukan besarnya nilai $\bar{X}$ dan $\bar{Y}$ sebagai berikut:

$$
\text { Rumus: } \quad \bar{X}=\frac{\sum N i=1 X}{K} \text { dan } \quad \bar{Y}=\frac{\sum N i=1 Y}{K}
$$

Dimana: K= Banyaknya atribut atau fakta yang dapat mempengaruhi kepuasan pelanggan (dalam penelitian ini $\mathrm{K}=10$ ).

$\overline{\bar{X}}=$ Skor rata-rata tingkat penilaian kerja

$\bar{Y}=$ Skor rata rata tingkat penilaian kepentingan

Berikut perhitungan skor rata-rata tingkat penilaian kinerja $(X)$ dan perhitungan skor rata-rata tingkat penilaian kepentingan $(\mathrm{Y})$ :

1) Perhitungan Skor Rata-Rata Tingkat Penilaian Kinerja (X) sebagai berikut:

$$
\begin{aligned}
\bar{X} & =\frac{\sum N i=1 X}{K} \\
\bar{X} & =\frac{32,83}{10}=3,283(\text { titik kordinat } \mathrm{X})
\end{aligned}
$$

2) Perhitungan Skor Rata-Rata Penilaian Tingkat Kepentingan(Y) sebagai berikut:

$$
\begin{aligned}
& \bar{Y}=\frac{\sum N i=1 \bar{Y}}{K} \\
& \bar{Y}=\frac{36,52}{10}=3,652(\text { titik kordinat } Y)
\end{aligned}
$$


Selanjutnya, agar lebih jelas mengenai letak indikator-indikator kualitas makanan di Harris Restaurant Pada Hotel Harris Raya Kuta dapat dilihat pada Diagram Kartesius dibawah ini:

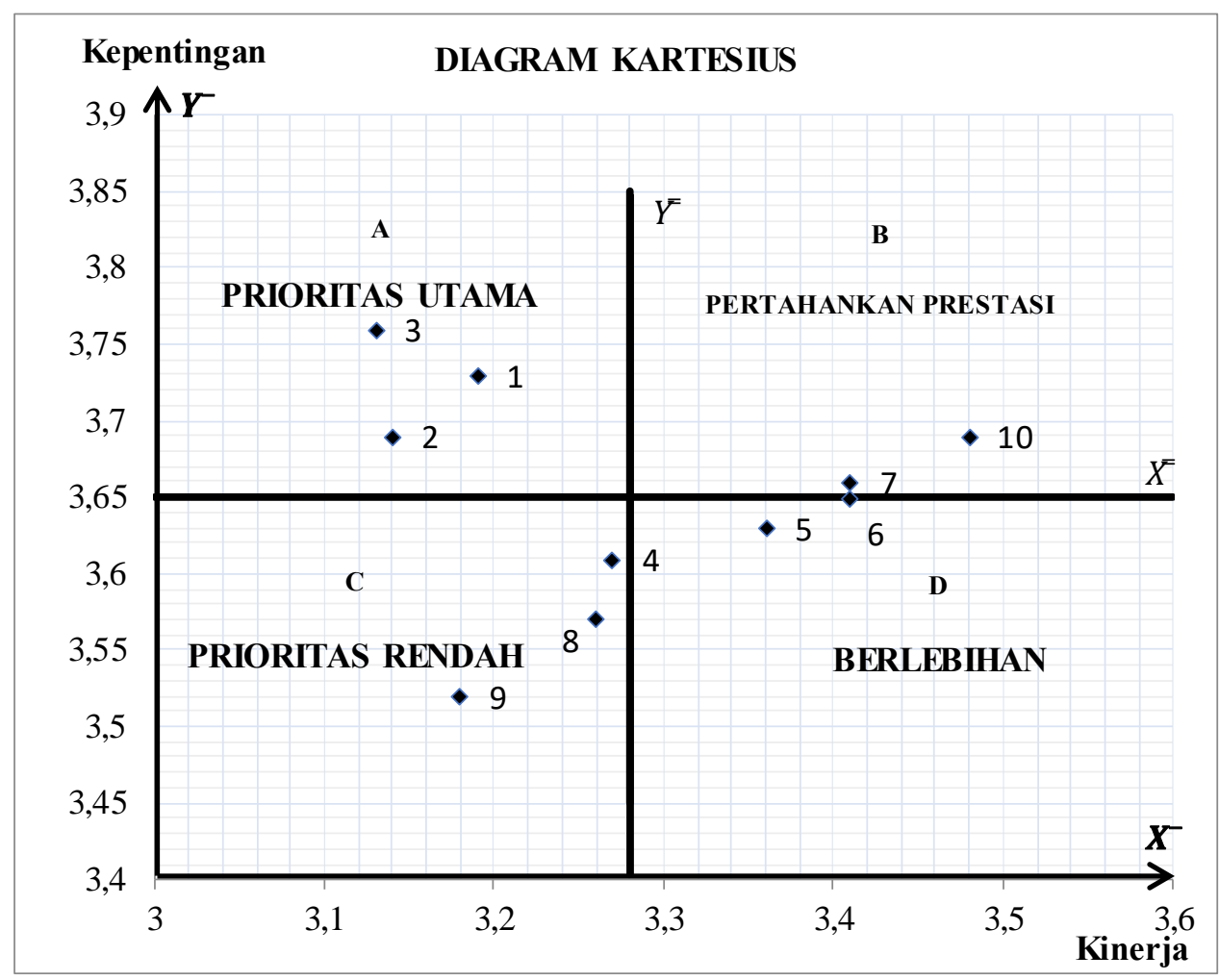

Sumber: Hasil Olah Data, 2019

\section{Gambar 3.1 Diagram Kartesius Indikator Kualitas Makanan di Harris Restaurant pada Hotel Harris Raya Kuta}

Berdasarkan Gambar 4.16 Diagram Kartesius dapat dilihat bahwa letak indikator/atribut kualitas makanan di Harris Restaurant pada Hotel Harris Raya Kuta terbagi dalam empat bagian, diantaranya:

1) Kuadran A (Prioritas Utama)

2) Kuadran B (Pertahankan Prestasi)

3) Kuadran C (Prioritas Rendah)

4) Kuadran D (Berlebihan)

Adapun penjabaran dari keterangan diatas dapat dijelaskan sebagai berikut:

\section{1) Kuadran A (Prioritas Utama)}

Pada Kuadran A menunjukan indikator yang dianggap penting dan menjadi prioritas utama kualitas makanan di Harris Restaurant pada Hotel Harris Raya Kuta, karena dianggap penting oleh wisatawan, namun kinerjanya dianggap belum memberikan kepuasan kepada wisatawan. Adapun indikator yang masuk dalam Kuadran A adalah kombinasi warna makanan yang disajikan oleh Harris Restaurant terlihat menarik untuk dimakan (1), makanan yang disajikan oleh Harris Restaurant memiliki penampilan yang menarik untuk dimakan(2), dan rasa dari makanan yang disajikan oleh Harris Restaurant memiliki kombinasi yang tepat sehingga terasa enak saat dimakan (3).

2) Kuadran B (Pertahankan Prestasi)

Pada Kuadran B menunjukan indikator dengan tingkat harapan yang tinggi dan tingkat kinerja yang tinggi juga. Indikator yang berada pada Kuadran B dapat dipertahankan oleh pihak Hotel Harris Raya Kuta, karena kualitas makanan yang disajikan mampu memberikan kepuasan kepada wisatawan. Adapun indikator-indikator yang masuk dalam Kuadran B adalah makanan yang disajikan oleh Harris Restaurant memiliki tingkat kematangan sesuai dengan jenis hidangan yang 
disajikan (7), sehingga baik untuk dimakan, makanan yang disajikan oleh Harris Restaurant dibuat dari bahan-bahan makanan yang segar, sehingga terasa enak saat dimakan (10).

\section{3) Kuadran C (Prioritas Rendah)}

Pada Kuadran $\mathrm{C}$ menunjukan indikator dengan tingkat harapan dan tingkat kineja yang rendah. Indikator yang berada pada Kuadran C diangap kurang penting oleh wisatawan dan juga pelaksanaan oleh pihak Hotel Harris Raya Kuta relatif rendah atau biasa-biasa saja. Adapun indikator-indikator yang masuk dalam Kuadran $\mathrm{C}$ adalah bentuk makanan yang disajikan oleh Harris Restaurant terlihat unik dan memiliki bentuk potongan yang bervariasi (4), makanan di Harris Restaurant disajikan dengan suhu yang tepat dan disesuaikan dengan jenis hidangannya (8), makanan yang disajikan oleh Harris Restaurant dapat bertahan dengan baik walaupun sudah disajikan dalam waktu yang cukup lama (9).

4) Kuadran D (Berlebihan)

Pada Kuadran D menunjukan indikator yang dianggap kurang penting oleh wisatawan, namun pelaksanaannya memberikan kepuasan bagi wisatawan di Harris Restaurant pada Hotel Harris Raya Kuta. Adapun indikator-indikator yang masuk dalam Kuadran $\mathrm{C}$ adalah makanan yang disajikan oleh Harris Restaurant sudah memenuhi standar porsi sesuai dengan jenis hidangan yang disajikan (5), tekstur makanan sudah sesuai dengan jenis hidangan yang disajikan oleh Harris Restaurant (6).

4.) Prioritas Kualitas Makanan Berdasarkan Tingkat Kesesuaian

Guna memperbaiki kualitas makanan di Harris Restaurant pada Hotel Harris Raya Kuta, maka terlebih dahulu menentukan indikator/atribut yang perlu mendapatkan prioritas. Penentuan tersebut dapat dilakukan dengan cara mengurutkan tingkat kesesuaian yang diperoleh dari masing masing indikator. Semakin rendah tingkat kesesuaiannya maka semakin perlu indikator yang dimakud mendapatkan prioritas, demikian juga sebaliknya, semakin tinggi tingkat keesuaian indikator yang dimaksud, maka semakin rendah pula prioritas indikator/aribut tersebut. Berikut pada Tabel 3.6 disajikan data urutan prioritas indikator kualitas makanan di Harris Restaurant pada Hotel Harris Raya Kuta berdasarkan tingkat kesesuaian:

Tabel 3.6 Urutan Prioritas Indikator Kualitas Makanan Di Harris Restaurant Pada Hotel Harris Raya Kuta Berdasarkan Tingkat Kesesuaian

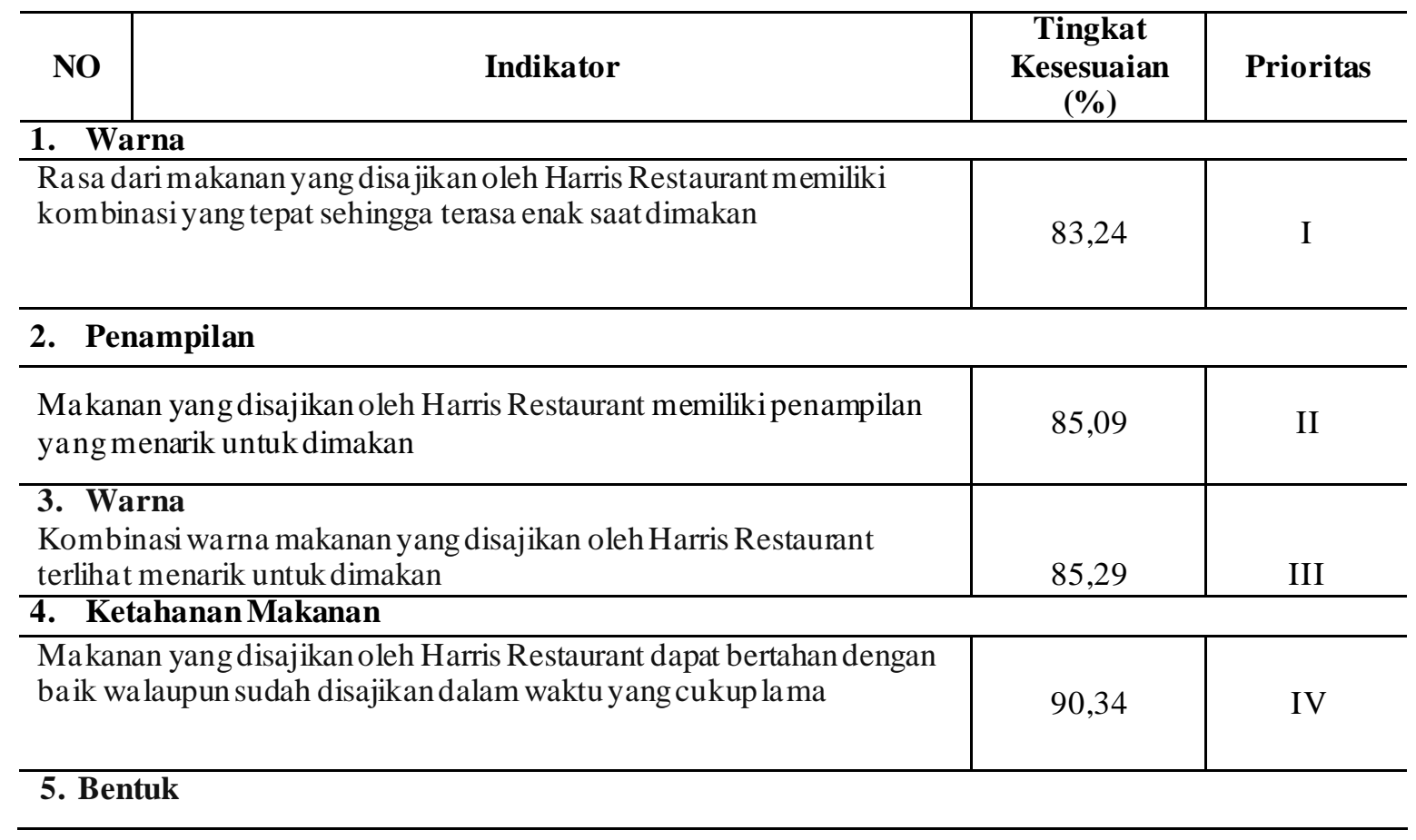




\begin{tabular}{|c|c|c|}
\hline $\begin{array}{l}\text { Bentukmakanan yang disajikan oleh Harris Restaurant terlihat unik } \\
\text { dan memiliki bentuk potongan y ang bervaria si }\end{array}$ & 90,58 & $\mathrm{~V}$ \\
\hline \multicolumn{3}{|l|}{ 6. Temperatur } \\
\hline $\begin{array}{l}\text { Makanan diHarris Restaurant disajikan den gan suhu yang tepat dan } \\
\text { disesuaikan dengan jenis hidangannya }\end{array}$ & 91,31 & VI \\
\hline \multicolumn{3}{|l|}{ 7. Porsi } \\
\hline $\begin{array}{l}\text { Makanan yang disajikan oleh Harris Restaurant sudah memenuhi } \\
\text { standar porsi sesuai dengan jenis hidangan yang disajikan }\end{array}$ & 92,28 & VII \\
\hline \multicolumn{3}{|l|}{ 8. Tingkat Kematangan } \\
\hline $\begin{array}{l}\text { Makanan yang disajikan oleh Harris Restaurant memiliki tingkat } \\
\text { kematangan sesuai dengan jenis hidangan yang disajikan, sehingga baik } \\
\text { untuk dimakan }\end{array}$ & 93,16 & VIII \\
\hline \multicolumn{3}{|l|}{ 9. Tekstur } \\
\hline $\begin{array}{l}\text { Tekstur makanan sudah sesuai dengan jenis hidangan yang disa jikan } \\
\text { oleh Harris Restaurant }\end{array}$ & 93,69 & IX \\
\hline \multicolumn{3}{|l|}{ 10. Kesegaran Untuk Dijadikan Makanan } \\
\hline $\begin{array}{l}\text { Makanan yang disajikan oleh Harris Restaurant dibuat daribahan- } \\
\text { bahan makanan yang segar, sehingga terasa enak saat dimakan }\end{array}$ & 94,30 & $X$ \\
\hline
\end{tabular}

Sumber: Hasil Olah Data, 2019.

Berdasarkan pada Tabel 3.6 di atas, dapat diketahui bahwa indikator yang memiliki tingkat kesesuaian paling tinggi adalah makanan yang disajikan oleh Harris Restaurant dibuat dari bahan-bahan makanan yang segar, sehingga terasa enak saat dimakan dengan tingkat kesesuaian 94,30 persen atau wisatawan merasa puas. Sedangkan 3 indikator yang memiliki tingkat kesesuaian paling rendah adalah rasa dari makanan yang disajikan oleh Harris Restaurant memiliki kombinasi yang tepat sehingga terasa enak saat dimakan dengan tingkat kesesuaian 83,24 persen atau wisatawan merasa puas, selanjutnya indikator makanan yang disajikan oleh Harris Restaurant memiliki penampilan yang menarik untuk dimakan dengan tingkat kesesuaian 85,09 persen atau wisatawan merasa puas dan indikator kombinasi warna makanan yang disajikan oleh Harris Restaurant terlihat menarik untuk dimakan dengan tingkat kesesuaian 85,29 persen atau wisatawan merasa puas.

Hal ini sesuai dengan komplain yang disampaikan oleh wisatawan, baik secara langsung ke Hotel maupun melalui online booking (Trip Advisior dan Booking.Com) yaitu adanya komplain terkait indikator rasa dan penampilan. Ketiga indikator ini sangat perlu menjadi prioritas untuk lebih di tingkatkan lagi oleh pihak Hotel Harris Raya Kuta dan juga dilanjutkan dengan indikator atau atribut lainnya sesuai dengan urutan priotitas pada tabel di atas, sehingga wisatawan akan tetap memberi kepercayaan dan akan merasa puas apabila sesuai dengan yang diharapkan.

\section{5.) Tingkat Kepuasaan Wisatawan Terhadap Kualitas Makanan Di Harris Restaurant Pada Hotel}

Harris Raya Kuta

Berdasarkan analisis tingkat kesesuaian yang dilakukan pada indikator/atribut kualitas makanan di Harris Restaurant pada Hotel Harris Raya Kuta yang mempengaruhi tingkat kepuasan tamu pada Tabel 3.7 di atas, maka diperoleh tingkat kepuasan wisatawan terhadap seluruh indikator dengan cara 
membagi jumlah tingkat kesesuaian dengan banyaknya indikator kualitas makanan. Jadi tingkat kepuasan wisatawan sebagai berikut:

$$
\begin{aligned}
\text { Tingkat kepuasan } & =\frac{\sum T k i}{K} \\
& =\frac{899,28}{10} \\
& =89,92 \%
\end{aligned}
$$

Berdasarkan perhitungan diatas maka diperoleh tingkat kepuasan wisatawan terhadap kualitas makanan di Harris Restaurant pada Hotel Harris Raya Kuta sebesar 89,92 \% atau wisatawan merasa puas terhadap kualitas makanan di Harris Restaurant pada Hotel Harris Raya Kuta.

Penilaian wisatawan berdasarkan Diagram Kartesius sesuai dengan komplain yang disampaikan oleh wisatawan pada tahun 2018, baik secara langsung ke Hotel maupun melalui ulasan online booking yaitu di Trip Advisior dan Booking.Com terkait indikator rasa dan indikator penampilan. Pada penelitian ini terdapat 3 indikator yang dianggap penting oleh wisatawan, akan tetapi pelaksanaannya belum memuaskan yaitu indikator warna dengan tingkat kesesuaian sebesar 85,29\%, indikator penampilan dengan tingkat kesesuaian sebesar 85,09\%, dan indikator rasa dengan tingkat kesesuaian sebesar $83,24 \%$.

Dengan demikian, pihak Hotel Harris Raya Kuta secara khusus Food \& Beverage Department harus tetap mempertahankan kualitas makanan yang telah disajikan kepada wisatawan, walaupun masih terdapat 3 indikator yang perlu ditingkatkan prioritasnya, sehingga kedepannya 3 indikator tersebut dapat memberikan kepuasan kepada wisatawan.

\section{KESIMPULAN}

Berdasarkan hasil dan pembahasan mengenai kualitas makanan terhadap kepuasan wisatawan di Harris Restaurant pada Hotel Harris Raya Kuta dapat disimpulkan sebagai berikut.

Adapun indikator-indikator yang telah memberikan kepuasan kepada wisatawan di Harris Restaurant pada Hotel Harris Raya Kuta adalah indikator makanan yang disajikan oleh Harris Restaurant memiliki tingkat kematangan sesuai dengan jenis hidangan yang disajikan, sehingga baik untuk dimakan dengan skor rata-rata 93,69 persen, makanan yang disajikan oleh Harris Restaurant dibuat dari bahan-bahan makanan yang segar, sehingga terasa enak saat dimakan dengan skor rata-rata 94,30 persen, makanan yang disajikan oleh Harris Restaurant sudah memenuhi standar porsi sesuai dengan jenis hidangan yang disajikan dengan skor rata-rata 92,28, dan tekstur makanan sudah sesuai dengan jenis hidangan yang disajikan oleh Harris Restaurant dengan skor rata-rata 93,69 persen.

Hasil penilaian wisatawan terhadap kualitas makanan di Harris Restaurant pada Hotel Harris Raya Kuta berdasarkan perhitungan tingkat kepuasan wisatawan terhadap seluruh indikator kualitas makanan diperoleh skor rata-rata sebesar 89,92 persen atau wisatawan merasa puas dengan kualitas makanan di Harris Restaurant pada Hotel Harris Raya Kuta.

\section{DAFTAR PUSTAKA}

Booking. Com. 2019. Harris Hotel Raya Kuta. Diambil dari: https://www.booking.com. Diakses 5 Maret 2019.

Hotel Harris Raya Kuta. 2019. Human Resources Department. Jumlah Kunjungan Wisatawan Tahun 2014-2018 dan Jumlah Wisatawan yang Melakukan Breakfast, Lunch, dan Dinner bulan JuliDesember 2018. 
Putra Suyasa. 2018. Persepsi dan Ekspektasi Wisatawan Terhadap Kualitas Menur Breakfast di Harris Café Hotel Harris Raya Kuta. Tugas Akhir Diploma IV Pariwisata. Tidak Diterbitkan. Fakultas Pariwisata. Universitas Udayana: Bali.

Rachman Arief. 2015. Pengantar Ilmu Perhotelan Dan Restoran. Yogyakarta: Graha Ilmu.

Sugiyono. 2014. Metode Penelitian Kuantitatif, Kualitatif, dan R\&D. Bandung: Alfabeta.

,2017. Metode Penelitian Kualittaif. Bandung: Alfabeta.

Sulastiyono. 2011. Manajemen Penyelenggaran Hotel.2011. Bandung: Alfabeta.

Trip Advisior. 2019. Harris Hotel Raya Kuta. Diambil dari: https://www.tripadvisior.co.id Dikases 5 Maret 2019. 